\title{
Integrating Quality Assurance in the Algerian Higher Education
}

Received: 09/10/2016; Accepted: 20/01/2019

\section{Abstract}

Many universities and institutions around the world have set up different internal and external mechanisms ensuring quality and best practices. Effective quality assurance systems beyond those institutions themselves are becoming of higher priority in national strategies. As a result, many countries worldwide have set up Higher Education (HE) quality assurance agencies at the national level. Although Algeria has followed their counterparts in adopting quality assurance programmes in Higher Education, the quality assurance (QA) system is still at an infant stage and confronted by many challenges. The purpose of this paper is to furnish local and global stakeholders with detailed information regarding the development and the current status of quality assurance in the Algerian higher education sector. This paper addresses the dearth of documented information on issues of quality assurance in Algeria. In addition, it discusses examples of QA programmes and best practices that could be emulated.

Keywords: Higher education (HE), Algeria, quality, quality assurance (QA), Higher education institutions (HEIs).

Keltoum Saadi *

Faculty of Letters and Languages Department of Foreign Languages

University of Mentouri

Constantine I

(Algeria)

\section{Résumé}

De nombreuses universités a travers le monde ont mis en place différents mécanismes internes et externes garantissant la qualité et les meilleures pratiques. Des systèmes d'assurance qualité au-delà de ces institutions elles-mêmes deviennent une priorité majeure dans les stratégies nationales. En conséquence, de nombreux pays ont mis en place des agences nationale de contrôle de qualité de l'enseignement supérieur. Bien que l'Algérie ait suivi ses homologues en adoptant des programmes d'assurance qualité dans l'enseignement supérieur, le système d'assurance qualité Algerien en est encore à ses debuts et confrontes de nombreux défis. Cet article essaye de fournir aux parties prenantes locales et mondiales des informations détaillées sur l'évolution et l'état actuel de l'assurance qualité dans le secteur de l'enseignement supérieur Algérien. Ce document aborde le manque d'informations sur les questions d'assurance qualité en Algérie. En outre, il présente des exemples de programmes d'assurance qualité et des meilleures pratiques qui pourraient être imités.

Mots clés: Enseignement supérieur , Algérie, qualité, assurance de la qualité (AQ), établissements d'enseignement supérieur (EES)

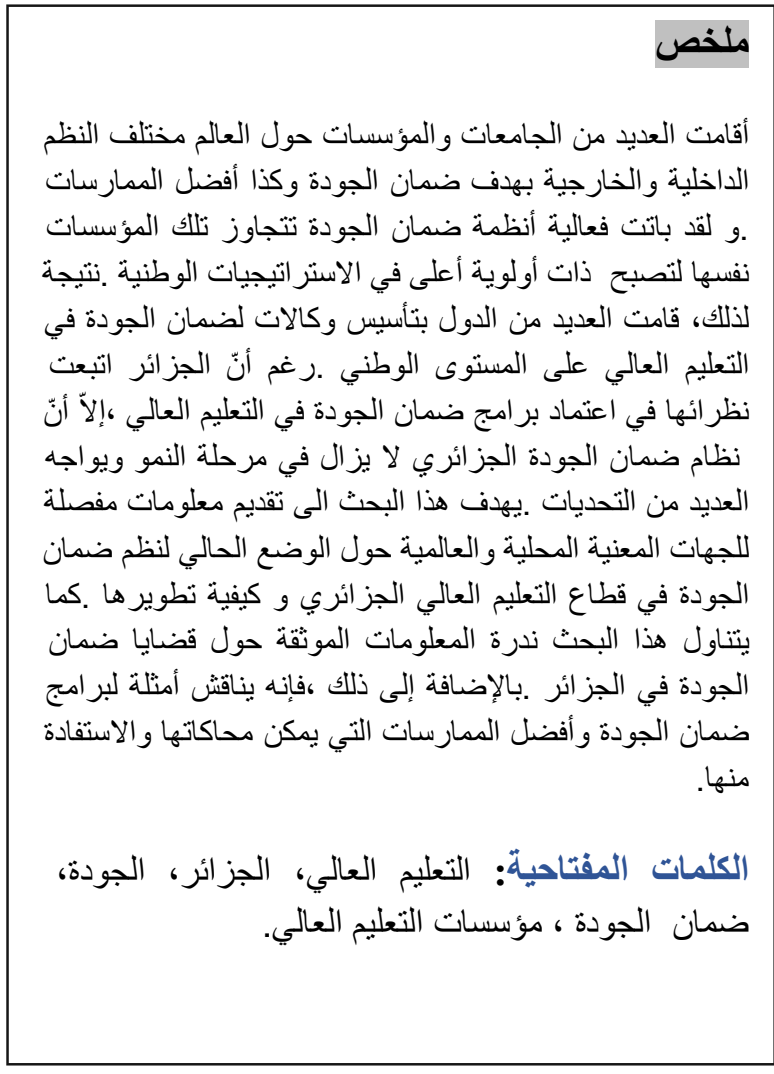

* Corresponding author, e-mail:s.kelthoum@gmail.com 


\section{I- Introduction}

Worldwide, higher education is witnessing major changes and transformations in its structure and organization. Quality assurance is one of the overarching themes in the higher education literature. It has emerged as an internal means of evaluating organizational performance and accountability in HE systems. For many scholars, quality assurance is intended to ensure accountability, to bring about improvement and also to monitor and maintain quality (Dill,1995 Houston,2008, Law,2010). In this context, Woodhouse (1999,p30) asserted that quality assurance "refers to the policies, attitudes, actions and procedures necessary to ensure that quality is being maintained and enhanced". Arafeh viewed it as review procedures that aim at ensuring academic standards and providing learning opportunities of a good quality for students (2009,p444).

In many countries in which a process of QA exists, national approaches that reflect different national styles have been established (Bruke,2005 ,Harman,1998, York, 1999). For example, the US has relied on private accreditation agencies that concentrate on institutional development and institutional improvement through peer-review and selfstudy. Also, they determine whether an institution or a program meets threshold quality criteria or not by examining various concepts regarding the institution. In contrast, the UK operates a system of auditing that examines the institution's QA and improvement processes and its programmes. In its attempt to give greater autonomy to HE, The Netherlands' peer reviewing and external QA systems are the responsibility of the institutions themselves rather than the purview of the government .

Higher education in developing countries has also been facing significant and persistent pressures towards expansion. This trend has led to significant pressures to adopt QA programmes and improve the quality of teaching and research (Lim, 1999,p.379, Teffera and Albach,2004 p.35). Algerian universities,like their counterparts elsewhere, are now in a process of advancing their institutions' prestige, competitiveness as well as quality outcomes.

\section{I.1-The Algerian Higher Education System: An Overview}

In Algeria, higher education (HE) is considered as the highest level of the educational system and the backbone of the country's human resource development. The Ministry of Higher Education and Scientific Research (MHESR), founded in 1970, is the central governing body of HE in Algeria. It is the only official organization responsible for initiating, implementing and reviewing reforms and programmes. The university of Algiers (established in 1909) is viewed as the foreground of the Algerian HE system as it was the only establishment (with two annexes : Constantine and Oran) that represented HE and scientific research (Ministry of HE, 2012, p21-24). The current system of higher education is split into two types of tertiary education institutions: public institutions under the supervision of the Ministry of higher education and scientific research (MHESR) and other institutions under the tutelage and the management of other ministries but are still under the supervision of the MHESR.The first type includes universities, Écoles Normales Supérieures (schools for training and forming primary and secondary school teachers), university campuses and Écoles Nationales Supérieurs (schools specialised in some vocational and scientific disciplines). The second type includes national training institutes and engineering schools (EACEA,2009,p5). In the last few years, the HE sector witnessed a dramatic expansion and an opening of a great number of universities and research centres. The following table summarizes these statistics. 


\begin{tabular}{|l|c|c|c|c|c|}
\hline & $2006 / 2007$ & $2007 / 2008$ & $2008 / 2009$ & $2009 / 2010$ & $2010 / 2012$ \\
\hline Universities & 26 & 26 & 33 & 35 & 35 \\
\hline University campuses & 16 & 16 & 12 & 13 & 10 \\
\hline Preparatory schools & - & - & - & 11 & 1 \\
\hline $\begin{array}{l}\text { Ecoles Normales } \\
\text { Supérieures (ENS) }\end{array}$ & - & - & 11 & 14 & 18 \\
\hline Ecoles Normales & 3 & 3 & 3 & 3 & 6 \\
\hline Laboratories & 22 & 17 & 45 & 59 & 188 \\
\hline
\end{tabular}

Table 1: The number of Higher Education establishments since 1962. Source: The Ministry of Higher Education and ScientificResearch. http://www.mers.dz/ National Statistical Office: http://www.ons.dz/-Annee-2007-a-2010-html

The number of students enrolled in these educational establishments reached 1.300 .000 student and 47000 university teachers in the academic year 2011/2012 (According to the Ministry of HE and the Ministry of Statistics (ONS)).

\begin{tabular}{|l|l|l|l|l|l|l|l|}
\hline & $1962 / 63$ & $1963 / 70$ & $1979 / 80$ & $1980 / 90$ & $1999 / 00$ & $2009 / 10$ & $2010 / 11$ \\
\hline $\begin{array}{l}\text { Students } \\
\text { enrolled in } \\
\text { graduation }\end{array}$ & 2725 & 12243 & 57445 & 181350 & 407995 & 1034313 & 1077945 \\
\hline $\begin{array}{l}\text { Students } \\
\text { enrolled in } \\
\text { post- } \\
\text { graduation }\end{array}$ & 156 & 317 & 3965 & 13967 & 20846 & 58975 & 60617 \\
\hline $\begin{array}{l}\text { Total } \\
\text { Permanent } \\
\text { Professors }\end{array}$ & 66 & 80 & 257 & 573 & 950 & 2874 & 3186 \\
\hline $\begin{array}{l}\text { Permanent } \\
\text { Teachers }\end{array}$ & 298 & 842 & 7497 & 14536 & 17460 & 37688 & 40140 \\
\hline
\end{tabular}

Table 2: The number of students and teachers from 1962 to 2011. Source: The Ministry of Higher Education and Scientific Research. http://www.mers.dz/

Higher education institutions are completely state-controlled including their funding. They are administered by rectors (universities) or directors (institutes, campuses). Rectors are directly appointed and removed by the Ministry at a very high level. Concerning academic programmes, the national curriculum which is a set of subjects and standards applies for all the institutions and universities. However, universities can determine their own teaching programmes for some specific subjects. Regarding funding, the government alone funds higher education in Algeria. Universities receive annual budget allocated by the state. Algeria's previous funding strategy, for the period 1990-1999, raised the budget for HE to $2 \%$ of gross domestic 
product (GDP). In the 2006 budget, 9\% of the state budget (nearly 226 billion Dinars) was allocated to higher education and scientific research.This percentage has been increased to $10 \%$ (557 billion dinars) in 2011. Additionally ,the budget for scientific research and technological development has been raised to $1 \%$ of the state gross domestic product in 2012. The rise, equivalent to 100 billion Algerian dinars (almost US $\$ 1.5$ billion) will be used to implement an ambitious science and technology programme over the next five years.

The Algerian university underwent a wide range of transformations and reforms such as the reform of 1971, 1982, 1999 and 2004 (Ministry of HE, 2012, p.23).These reforms aimed at restructuring, consolidating and rationalizing the system with regard to the socio-economic changes in Algeria. The prevailing system from 1970 to 2004 known as the 'classical system' includes two levels: undergraduate and graduate or postgraduate. It involves three cycles: Licence, Magistère and Doctorat d'Etat.

\section{2.The LMD Reform}

For the development and modernization of higher education, the Algerian Ministry of $\mathrm{HE}$ has adopted a large-scale reform called The Credit Transfer Accumulation System. It is inspired from the Bologna Process (BP) which was initially signed and adopted by 29 European countries in 1999. The ultimate goal of the BP is to create a European Higher Education Area (Jing, 2008, p608).According to the Algerian Ministry of HE, the LMD system is designed to align the Algerian HE with international systems. It offers three types of degree programs: Licence (equivalent to the Bachelor degree), Master (equivalent to the Master degree), and Doctorate (equivalent to the $\mathrm{PhD}$ degree). This reform has been explicitly implemented in the academic year 2004/2005. The Ministry of HE in its decision to initiate The LMD had four separate objectives in mind, namely:

-Building a single system in all Algerian universities to ensure that the degrees (Bachelor,Masters,Doctorate) obtained in this system have the same value as those obtained in all European countries.

-Increasing the number of students as well as lecturers, professors and university educators ;

-Restructuring the educational and training programmes ${ }^{1}$ and

- Reconstructing higher education infrastructures.

\section{I.3.The Introduction of Quality and Quality Assurance in Algeria}

In the area of HE, quality is multifaceted concept and it is not amenable to different performance criteria or simple metrics. It means many things to many people.Former ways of thinking have associated quality with the idea of inherent excellence, distinctiveness and high achievement (Garvin, 1984). Others such as Harvey and Green (1993,p.9) defined five approaches to quality. They see it as exceptional, perfection, fitness for purpose, value for money and transformative. Lindsay (1992, p.154) discerns two approaches to quality: production-measurement( namely performance approach) and stakeholder-judgement approach.Badely (1993,p.23) views quality as a slippery and elusive concept that has no exact meaning in HE. He said:

What the university doesn't need, in my view, is a simplistic definition of quality. Quality is one of those especially slippery and empty terms which confuse us when we try to pick out a set of defining characteristics. Quality is what philosophers call 'an essentially contested concept', its contentedness coming from its being descriptively or cognitively weak at the same time as it is emotively powerful. Its status is high, its prestige is great, its trouble-making and

\footnotetext{
${ }^{1}$ It is worth noting that most HE programmes are taught either in Arabic and/or French with English only sporadically used.
} 
mystifying character is immense and yet its meaning is elusive and vague.

Not long ago, Algeria was discussing quality, quality assurance and self-evaluation just as many countries in the world.The transformation of education policy and the restructuring of $\mathrm{HE}$ in recent years in the country gave rise to calls to integrate quality and quality assurance programmes in the system. Education policy-makers continue to express concern about the state of higher education as well as its quality. In this context,the previous Minister of higher education and scientific research Mr. Mohamed Mebarki stressed the need for high-quality education under such varying circumstances. He said :

The aim is to reduce the leakages recorded earlier, open the socio-economic environment of the country and to be in line with international standards by improving the quality of education...the Algerian university must meet the needs of the socio-economic environment of the country and get involved actively in its development ( Algeria Press Service, 2014).

With the absence of a national QA system during the 80's,90's and early 20's, the approach to what is intended by the word quality itself in Algeria was not clear. The culture of quality and quality assurance (mainly internal QA) in HE began to settle through a series of meetings and conferences such as the national conference of higher education and scientific research and the international forum on quality assurance in higher education in May 2008 and June 2008 respectively.Accordingly, The MHESR views quality assurance as "the set of means by which an establishment can guarantee with confidence and certainty that the standards and the quality of education it provides are maintained and improved" (https://www.mesrs.dz/assurance-qualite1). In 2010, a national committee known as CIAQES (committee for the implementation of quality assurance in Higher Education) was set up to establish a QA system for HE in Algeria. The CIAQES does not precisely identify what is meant by the word quality in itself, yet institutions should achieve these goals:

- Setting up and promoting QA principles and practices in HE institutions through the elaboration of a QA programme.

- Providing relevant and effective QA practices to introduce internal QA in universities

- Helping in the creation of a national agency for evaluation

- Providing training and events to help QA coordinators develop and improve their competences

- Sharing information about the process of QA with all HE stakeholders and providers

The committee's first job was the formation of what is so called quality assurance cells/units at the level of each university. The unit member's' mission is primarily the establishment of a policy or a set of procedures to integrate QA mechanisms in their institutions. Moreover, they should conduct assessment questionnaires and surveys for both teachers and students in order to evaluate the progress in the proceeding of quality plans and their impact within the academic institutions.

\section{II-Quality Assurance Processes in Algeria}

The quality and efficiency in Higher Education (HE) became the keys to gaining entry into the global scientific communications. There is a wide agreement that quality and assurance of quality are important concepts for the development of HE all over the world (Lindsay 1992, Harvey and Green 1993, Yorke 2006).

Quality and quality assurance (QA) are relatively new concepts in Algeria's higher education. They are in their early stages of discussion and implementation. Interested parties are determining which techniques should be used and when and where they should be applied.

Algeria's transition to the LMD reform in line with trends in quality assurance in HE required all existing practices, institutions and values to be viewed again and re-thought in terms of their adequacy and compatibility for the new era. As the principles and practices of quality assurance are further embedded in HE, methodological questions 
about how to understand and manage quality become increasingly important.Therefore, it is important to critically review and evaluate the policy and the actual QA procedures with the belief that this will foster ultimate objectives. This review and analysis will be done on the basis of reports and documents issued by the Ministry of Higher Education and Scientific Research, CIAQES, QA cells, the consortium of universities and conferences and different workshops held in Algeria.The main results of the three workshops held in Algeria emphasises the following objectives for initiating a quality audit programme in HE, namely:

-Focusing more on continuous improvement of quality and developments rather than accountability or punitive sanctions when undertaking external quality audits.

-Allowing institutions to choose a foreign QA agency for external audits.

-Developing a quality assurance model that considers the existing international models. -Assisting universities in establishing internal quality assurance systems through selfevaluation (through the AqiUMed project:Strengthening the Internal Quality assurance at universities in the Mediterranean Algeria-Morroco-Tunisia 2010-2013) (La Commission d'Implémentation d'un Système d'Assurance Qualité dans les Établissements d'Enseignement Supérieur (CIAQES), p.70).

\section{II-1-Internal Quality Assurance Processes}

With the belief that sustainable improvement relies on internal engagement, the MHESR emphasises the use of self-evaluation processes as an instrument to be used in internal QA system. Therefore,Universities are engaged in self-evaluation processes through the AqiUmed project.

\section{The AqiUMed Project and its Implementation}

To respond to these growing concerns about assuring quality in higher education, Algeria joined a European project called AqiUMed. ( renforcement de l'assurance qualité interne dans les universités de la Méditeranée Algérie, Maroc, Tunisie 20102013 : Reinforcing internal quality assurance in the Mediterranean universities Algeria, Morocco,Tunisia 2010-2013). This project is part of the " structural measures" of Tempus program (http://eacea.ec.europa.eu/tempus/) which is funded by the European commission and aims at supporting the modernization of HE systems and enhancing the cooperation in universities of the partner countries of Eastern Europe, central Asia, the west Balkans and the Mediterranean region. The main objective of the Aqi-Umed project is to establish a process of internal evaluations and strengthen the internal quality assurance processes in universities of Algeria, Morocco and Tunisia. Three of the European union member states( Belgium, France, Spain), ten institutions of the Maghreb states (Algeria,Morocco, Tunisia) with their ministries of higher education ( as associated partners) in addition to the agencies responsible for external evaluation ( The National Agency for Quality Assessment and Accreditation of Spain (ANECA) and l'Agence d'évaluation de la recherche et de l'enseignement supérieur (AERES) from Spain and France) and two individual experts compose the consortium of this project. This latter is implemented through 5 various phases each of which has its own objectives and characteristics ( http://www.aqiumed.org/).

\section{a-Methodological Approaches and Project Launch ( Jan.2010-Apr. 2010)}

It is the first part of the project in which the objectives, the mission, and other methodological concepts were discussed and presented to all the participants. This has resulted in the establishment of a specific committee called 'comité de pilotage' at the level of each university. Its role is to make a work plan for the internal quality procedures that each institution will carry out and prepare a number of reports on the national evaluation policies each country is applying.

\section{b-A Comparative Approach to Quality Assurance (May 2010- Dec.2010)}

During this phase, quality experts were in a mission to the Maghreb universities to assess the conduct and the execution of the project as well as the organization of the quality operations. Initially, three Algerian institutions were concerned with this 
project: Mentouri university (constantine), M'Hamed Bougara university (Boumerdés) and l'École Normale Supérieure d'Enseignement Technologique (Oran). National workshops also were designed within every university to develop universities skills for the self- evaluation of their resources and to determine the methodology of constructing an internal-evaluation framework (Commission Europeenne TEMPUS,2010, p.1). Furthermore, a series of visits to European universities (mainly to France,Belgium,Spain) were organized in this phase. The aim was to observe and analyse the assessment practices and procedures in these european universities in the fields of research, training, governance and life at the university.

\section{c-The Elaboration of Common Assessment Standards ( Jan. 2011-Dec.2011)}

The year 2011 is considered as a critical year of the Aqi-Umed project. It aimed at the construction of a final framework based on a number of references and criteria which can be common to all partner institutions or shared by some of them. Hence, each institution was invited to participate in the development of these quality references. This has been realized through a number of intra- Maghreb study visits in the partner universities, the elaboration of the evaluation fields that each university will consider and a series of international seminars for the presentation of the assessment framework. Additionally, a second series of national workshops were organized in every university to define the self- assessment criteria and evidences of the QA specific to the context of each university (kamel,2011,p.18) and also to determine the fields that will be subjected to evaluation in each university (eg. Training, research, socioeconomic development...etc). Extensive work had been carried out on each field subjected to self- evaluation procedures in each university with the aim of contributing to the development of the internal quality references. The final version of the framework and the validation of the references (in october 2011) was presented in an international seminar held in Algeria and organized as showed in figure1:

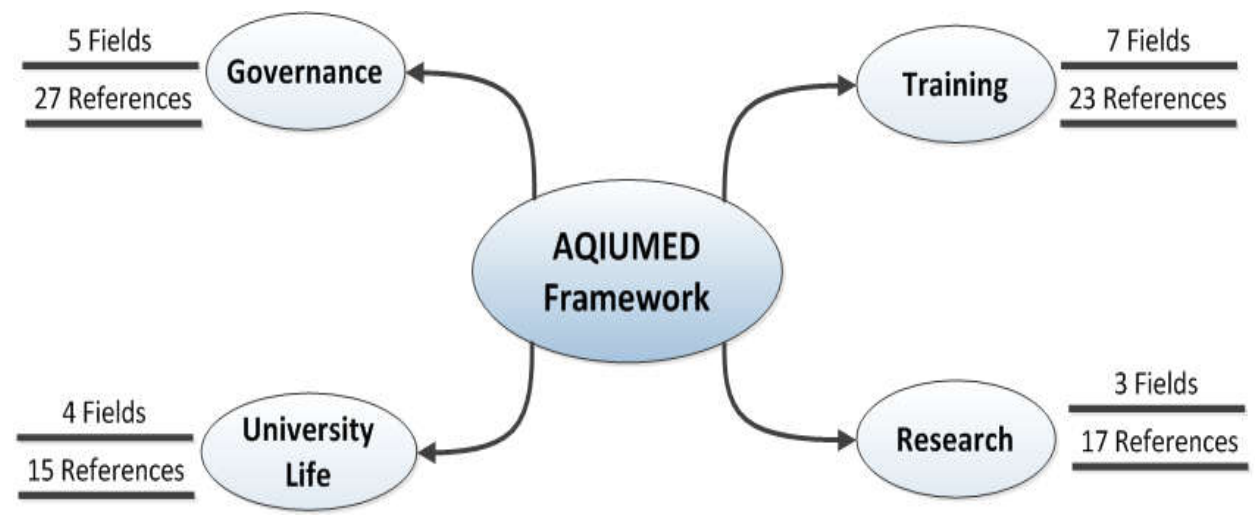

Figure 1: The framework of the AQIUMED project. (Source: Présentation des ateliers nationaux par l'université M'hamed Bougerra Boumerdes; phase03. Referenciel AqiUMed version finale, october 2011).

\section{d-Self-Evaluation Practices within Partner Universities ( Jan. 2012-Sep.2012)}

In phase 4, universities were appealed to collect and analyse data in the fields of research, training, governance and university life for the purpose of producing a report known as 'rapport d'auto-evaluation ( self evaluation report). The evaluation reports produced by each Maghrebi university member should be validated by either the university president or the rector before their publication. Then, the members of the committee should also validate all the reports. A third series of national workshops commenced in september 2012 (in Algeria, Morocco, Tunisia) in order to present and discuss the internal evaluation reports of each partner university as well as the limitations and shortcomings encountered during this process. Other aspects such as the achievements of the year, the methodological considerations related to assessment procedures had also been discussed.

e-Assessment, Development and Dissemination (Aug. 2012-Dec. 2012) 
This phase was the final stage of the project. A booklet called 'Aqi-Umed Booklet' was produced and distributed not only to the partners involved in this project but also to a wider audience including all universities and higher education ministries and institutions within these countries. The booklet addressed the project results, the Maghreb institutional framework of self- assessment and also how it has been implemented in details (http://bookr2.com/viewmanual/1450880)

\section{II-2-Self-Evaluation Practices}

Borrowing from the European trends of QA in the world, the Algerian QA plan begins with self-evaluation undertaken by institutions to compare their instructional conditions, strengths and weaknesses with the QA indicators set up by the AqiuMed project. Almost all HE institutions are concerned with the self-evaluation at the institutional and programme levels .The main goals of the self-evaluation procedures are the following:

-Conducting a self-critical review of the institution's performance in the fields of training, research, governance and students' university life.

-Identifying the institutions' strengths and weaknesses (capacities and limitations)

-Providing a basis for external evaluations and then accreditation.

For the institutional evaluation, universities are subjected to the evaluation of five different segments including pedagogical management, information system, issues of employability, resources (libraries, multimedia, cyberspaces) and university life. In addition to preparing assessment materials for this process, institutions are also in charge of reinforcing the cooperation among various departments, faculties and administration offices internally. The self-assessment reports are submitted to the CIAQES and then to the MHESR.These reports are seen to be a basis for the steps that can be taken in the future.

\section{How Does it Work?}

As Figure 2 demonstrates, self-evaluation is followed by external audits from evaluation specialists. Building on this source of information, universities have to recognize their strengths and shortcomings and then make the needed reforms. The interactions between QA responsibles, teachers, students and administration staff are important in the implementation of each stage.The systematic evaluation at the institutional and programmes' level began in 2012 with only 3 institutions. In the first stage, the AqiUMed reference book provides indicators, criteria, and other relevant factors for the internal evaluation. At this stage, universities establish a steering committee only for the self-evaluation process. QA cells are always associated to this committee (Boubakour,2015. p15). Also, universities select the areas of evaluation (training, research, governance and students' university life). Both the university of Mentouri- constantine and university of M'hamed Bouguerra Boumérdes have chosen training and research as the first fields to be evaluated. Questionnaires, which are considered as a self-evaluation tool, have been conducted essentially to examine students' satisfaction and the functioning and the attitudes of these institutions. Records of self-evaluation procedures are important information to enable regular and constant improvement. These records are the basis of the evaluation report that should include the checks and reviews that were performed, when they were performed and who performed them. Later on, this report will be sent to the CIAQES. 


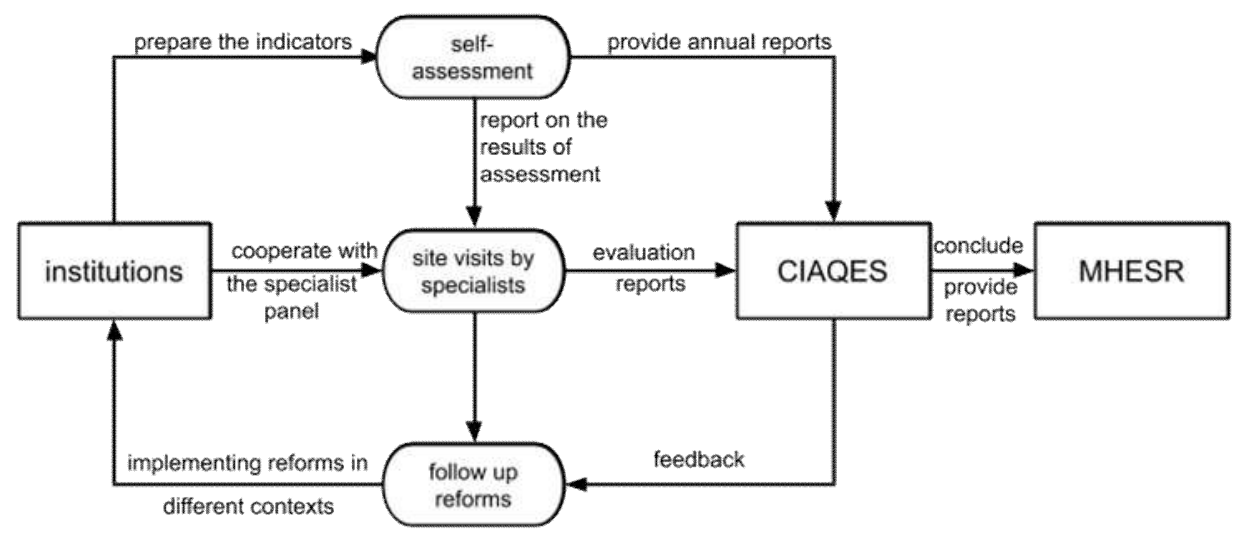

Figure 2: The proposal process of quality assurance.

\section{II-2-External Quality Assurance}

In the second stage, institutions are in charge of carrying out external actions by engaging external bodies which may be a QA agency or any body other than the institution. They are allowed to choose a foreign QA agency for this purpose but all under the supervision of the MHESR. Based on the specialists key findings (who visit the institution under question to determine whether it is meeting the agreed or predetermined standards), institutions should improve and enhance their institutional performance. In this context, two faculties from the university of Mentouri-Constantine (Faculty of Medicine and faculty of Urban planning) have asked for external audits from CIDMEF (International Conference of Deans and French Expression of Faculties of Medicine) and APERAU (The association for promoting teaching and research in urbanism) respectively. Data on the results of external evaluation is not published.

\section{III-The Purpose of Quality Assurance}

\section{III-1-Improvement}

Many researchers and academics have noted that the introduction of QA processes should always consider the purpose and the context in which it is practiced. In this context, Harvey and Williams(2010,p7) note that " the analysis of quality should not be detached from purpose and context and that quality has political dimensions and is about more than (consumer) satisfaction".

Generally, quality assurance can deliver two major purposes: improvement and accountability. Quality procedures for improvement purposes aim at promoting future performance rather than making judgement on post or previous performance. In a broad sense, the criteria of improvement refer to those conducive procedures that are intended to strengthen the conditions, motivations, scope and level of information of the HE institutions (Thune, 1996,p.22). QA for improvement purposes implies formative approach. Within this approach, the focus is more likely on improving quality rather than controlling. The final reports of evaluation under this approach usually tend to put a clear emphasis on recommendations and ways of improvement rather than making judgments or giving grades ( Billing, 2006,p.121). In countries where the state strongly regulates the HE sector such as Algeria, the common approach to QA is formative , identifying the relevant areas for potential improvement.

\section{III-2-Accountability}

Colleges and universities have been and will continue to be accountable to their customers; their students. Middlehurst and Woodhouse (1995,p.260) defined clearly the notion of accountability as follows: 
A central aspect of accountability in any form is that of rendering an account of what one is doing in relation to goals that have been set or legitimate expectations that others may have of one's products, services or processes, in terms that can be understood by those who have a need or right to understand the 'account.

Mortimer (1972,p.10) has claimed that accountability is characterized by the following:

-Effectiveness and efficiency

-It is concerned with the notion of external judgement

-Accountability assessors tend to have more expertise in business and finance compared to evaluators who are often academics or educational researchers

-Accountability implies that universities must be accountable both externally (to the community) and internally (to the students)

Quality procedures for accountability are usually based on criteria formulated by external authorities and institutions. They aim at strengthening external insights and control, and possibly allowing external corrective actions when necessary. Quality assurance for accountability purposes implies the use of summative approach where the final report must be comprehensive and consistent including explicit statements of outcomes. The reports are basically published to inform the public about the performance of HE institutions. This approach is common in countries, such as the UK, where there is a considerable institutional autonomy (Billing,2004,p.121).

The current pressures on universities to be effective and efficient in time of financial stringency make the concepts of improvement and accountability of a great significance. It is widely accepted in Algeria's HE system that quality assurance can be used as an instrument to continuously improve the system, establish accountability and therefore enhance and monitor quality within institutions. Theoretically both aspects have been addressed in Algeria with a great focus on promoting and improving quality rather than accountability. The previous Minister of Higher Education and Scientific Research, Mebarki Mohamed, said that improving the quality of higher education is "a priority" for his department (Algeria Press Service,2014).

Boujaadar and Kherief (2010,p.64) and Bouzid (2010,p.151) have dealt with the concept of accountability as follows:

The second reason is related to the obligation of 'rendering an account' with regard to the use of enormous resources and significant financial credits granted by the state to the university. A quality assurance system that results in a real rationalization and a better orientation of resources towards expense items that produce true results (...), here is a strong signal that the university is obliged to transmit to society.

\section{IV-Reactions and Criticisms}

Overall, the system has positive implications for institutions themselves on the one hand and for various $\mathrm{HE}$ stakeholders on the other hand. Both government and institutions themselves now are investing more effort and resources on quality assurance processes.However, the initiation of QA system has also brought some problems in terms of organization, lack of autonomy and respecting deadlines.

\section{IV-1-Positive Impact}

Changing Relationships between Government and HEIs: as the state is the direct provider of universities of HE in Algeria, it is concerned about return on investment as well as academic quality. The introduction of QA processes in addition to the 
installation of QA cells at the level of faculties and departments gave rise to the idea of adequate administration of the state's funds as well as evidence of students learning outcomes. Universities now can see the state not only as a provider but also as a supervisor.

Greater Attention to Shortcomings: Through self-evaluation, universities become aware of their strengths and more importantly of the gap between the evaluation criteria and the actual situation. Because of the assessment process, universities now are able to develop their own internal processes for uncovering areas of weakness in their functioning such as lack of internal training,students supervision, tutoring and lack of local network for the whole institutions.

Setting up Official Agencies for Quality Assurance: The Algerian government is mainly responsible for setting up official organizations for QA and evaluation through the MHESR and formulating corresponding policies in HE. In this context,several committees and agencies have been established such as CIAQES and The National Committee for Evaluation (CNE) (Berkane, 2010, p.26). Additionally, many universities set up their own QA cells at the level of faculties and departments and organized academic conferences in order to integrate concepts of quality and QA in their education plans. The creation of such bodies have a positive impact in promoting research on QA mechanisms, expanding cooperation with similar agencies abroad and working on internal evaluation to improve the governance of universities

New Strategic Plans and Goals: With the initiation of QA procedures, many universities rethink their philosophy and vision regarding the quality of their structure and functioning. Particularly, the self-evaluation phase gives HE institutions the opportunity to express their viewpoints on strengths and weaknesses in different key area and enables long range planning to be possible.Similarly,the MHESR is truly developing a remarkable plan and setting up forth new directions and parameters for a congruent system of quality in HE by 2030 . The strategic plan focuses on developing a robust QA system, adequate self-evaluation methodologies and a national qualification framework (Miliani, 2013, p.203) .

\section{IV-2-The Deficiencies}

While it might be true to say that the definitions of QA are vast and confusing, the process has brought with it a rational change and a drastic paradigm shift from a protected to exposed system in the Algerian HE system. The MHESR has partially succeeded in establishing some QA procedures and mechanisms in many universities within the country. Nevertheless, important methodological and tangible weaknesses embedded in the current system can be noticed and further work is needed.

The Absence of a National Quality Assurance Framework: The initiation of QA in the Algerian HE was through the implementation of procedures rather than a robust or coherent system. A formal QA framework that entails a detailed examination of those characteristics related to the various programmes, trainings and the products of universities does not yet exist in Algeria.This has resulted in a very poor regulation, planning and control in many universities with respect to quality assurance.

Lack of Authority: Despite the initiatives to install QA policies and mechanisms and the establishment of a national commission for this purpose in Algeria, the role of the Ministry of Higher Education and Scientific Research remains stronger than in many European countries. El Hassan (2013,p81 ) noted that some QA associations including the ones in MENA countries are in a transitory phase and have not yet arrived at an independent structure with their own moral authority. Accordingly, their significant impact on HS institutions cannot be noticed and their criteria and standards can not be seen as an intrinsic part of HE policy.

Rewarding for Quality: Rewards linked to institutional or research performance usually motivate universities to improve and foster their quality. Additionally, these rewards will systematically engage researchers and academics in quality and improvement matters. The current system has been criticized as it does not provide any 
reward or penalty on the performance of institutions. Funding bodies should direct financial support to those institutions that have achieved good results to create a competition and then the quality will be surely improved. The Algerian Ministry of HE need to articulate both research institutions and researchers' expectations and find ways to establish an incentive system for them.

The Ranking Tables that are generally used to compare the university performance to other universities are very prominent tools for measuring its achievement and more specifically its quality. This issue seems to be unseen in the debate around HE system in Algeria. The current system does not generate,even locally, such rankings and league tables. The lack of an annual reporting of performance data does not allow the sector benchmark and compare the progression, completions, and graduate outcomes of $\mathrm{PhD}$ students and researchers as well.Additionally, the echo of the success stories and the positive reports is only known by the university not the media.This may not improve the quality of research as the absence of such quantifiable results on the research performance will break down the morale of many universities and also researchers who have attained excellent results or high quality outcomes.

Data Availability: one of the main problems when dealing with QA issues in the Algerian HE system is the lack of data which does not exist most of the times or is not publicly available. Moreover, it is quite common to find only aggregated data on how the self-evaluation is carried out without referring to the details of each procedure or quality indicators. Any solid documents to reflect the QA reviews and external audits' findings could not be cited as universities do not disseminate such reports or results.This will make it too difficult for researchers and stakeholders to make fair and reliable judgements on universities performance.

Absence of Professional Accrediting Bodies: Accreditation processes provide confidence to the governments, employers, and students on the quality of education. The accreditation of programmes and courses of HE providers is a key element in any QA framework. However, accreditation bodies and procedures do not exist in the Algerian QA national policy (Arafeh,2009,p.447). Many scholars argue that the assessment of programmes and courses may possibly lead to the de-registration of these programmes and ends up with the closure of many public HE institutions (Bouzid and Berrouche, 2012,p52).This will result in poor regulation and planning of HE in Algeria as the Ministry and the government will not be able to do benchmarking or comparisons across the sector. Moreover,the absence of an accreditation body to accredit HE institutions and their courses means poor and inconsistent quality management and lack of oversight in universities.

\section{V-Conclusion and Future Directions}

It is evident that the Algerian universities are in a process of development and strategic construction with regard to their mission, objectives and QA practices. The demands placed upon HE from the labour market and stakeholders signal the need for setting up rigorous QA mechanisms and processes. The future policy in HE should concentrate on setting up a high standard-based QA framework. The need for this framework is justified by the level of public funds being invested in this field, the calls for transparency, accountability and also by the attempts to compete in the global market. The setting of such framework by the MHESR should emphasize evaluation on the basis of the university history, its mission, its current performance, and its resourcing. In other words, it should take into account distinctive characteristics of universities and their infrastructures or means needed to achieve their targets.

HEIs in Algeria should continually assess their courses and systems and take them as an instrument of quality improvement and QA. Although the creation of QA units was a positive move to the development of internal QA in universities, the lack of systematic internal QA mechanisms within was a worrying trend. An internal organised self-evaluation framework does not exist yet. 
A consistent QA system involving collaboration between internal and external QA systems is truly needed. The current QA policies and their associated procedures such as the existing ones could be maintained but apart from working with the MHESR. The CIAQES should have a strong financial and staff base and be truly independent from the MHESR. The main challenges to the CIAQES is to establish a strong QA framework, gain credibility, commit itself explicitly to the development of quality culture and QA. Additionally, it should be independent ,able to create ongoing funding for its activities and operate within the expectations to deliver services that enhance and harness QA in HE in the country.

In order to be able to shape and pursue their own objectives, evaluations of HE institutions should be initiated as an internal process at first. All the institutions should implement adequate quality assurance systems internally (only three institutions are engaged in the Aqi-UMed project for supporting internal quality assurance). A focus on this self- evaluation will allow the institution to supply genuine and relevant information about itself either to internal (researchers, students,academic staff,...etc) or external stakeholders( Ministry, government,...etc). Also, it gives the institution a clear view on its deficiencies and weaknesses .

External quality audit panels consisting of appropriate specialists is another instrument of evaluation that should be taken into account and the results will be fairly used to reward or penalize institutions. The predominant situation in Algeria reveals that national authorities lack the competence to make judgements about the quality of academic programmes and institutions.Hence, there is need for a strong external QA agency (QAA) .The role of this independent agency is to review how individual universities meet their responsibilities for maintaining quality and standards. Making regular visits to all universities to scrutinise and report on their internal processes for maintaining quality are also one of its main tasks.In most countries in the west, especially Australia and the UK, all universities subscribe to an external QA agency.

collaboration and partnership with foreign institutions and QAAs with sound QA experience are critically necessary in the Algerian HE system.Thus, high quality educational partnerships with faculties and institutions abroad such as Australian Universities Quality Agency (AUQA) and the Quality Assurance Agency for Higher Education (QAA) in the UK should be in the broad interests of the HE system. However, developing partnerships with international foreign institutions is not always easy, collaborative or appreciated and sometimes it becomes a crux source of dependency, dispute and domination.

The system will continue to evolve in Algeria. Recent policy pronouncements such as the national medium and long term plan (2010-2030) highlights the importance of QA by setting evaluation objectives and criteria including performance indicators , national standards and organizational standards. 


\section{Referrals and References}

[1] Arafeh, Labib. "Quality assurance review in Arab countries". Towards an Arab Higher Education Space :International challenges and Societal Responsibilities. 31 May, 1, 2 June 2009, Cairo. 2010

[2] Badley, Graham. "The Quality Debate in Higher Education." British Journal of In-Service Education 19.3 (1993): 23-28. Web. 23 May 2014.

[3] Berkane, Yousef. Assurance qualité dans l'enseignement supérieur en Algérie : Exigences et préalables. Colloque international sur Les enjeux de l'assurance qualité dans l'enseignement supérieur. Skikda, Algeria, 20-21 November 2010.17-30

[4] Billing, David. "International Comparisons and Trends in External Quality Assurance of Higher Education:Commonality or Diversity?" Higher Education 47.1 (2004) : 113-137. Springer. Web. 2 1Dec. 2014.

[5] Boubakour, Fares. "Assurance Qualite interne et Autoevaluation : Des Principes a la mise en oeuvre"." 4 ème Session De Formation Des Responsables D'assurance Qualité Des établissements D’enseignement Supérieur (MESRS), Benaknoun Algiers, n.d. Web. 13 March 2015. Lecture.

[6] Boudjaadar, Djamel, Kherief, Mohamed. "Le projet de mise en œuvre d'un dispositif assurance qualité à l'université 20 Aout 1955 - skikda." Colloque international sur les enjeux de l'assurance qualité dans l'enseignement supérieur, Skikda Algeria, 20-21 Nov. 2010. 63-73.

[7] Bouzid, Nabil. "La qualité de l'enseignement supérieur et son évaluation." Colloque international sur Les enjeux de l'assurance qualité dans l'enseignement supérieur. Skikda Algeria, 20-21 November 2010. 149-164.

[8] Bouzid, N. et al. Assurance qualité dans l'enseignement supérieur . Commission Nationale pour l'implémentation de l'assurance qualité dans l'enseignement supérieur (CIAQES). Algiers. 21-23 October 2012. Lecture. Microsoft PowerPoint file.

[9] Commission Europeenne TEMPUS. Referenciel AQI-UMED Version Finale. France :Centre international d'études pédagogiques (CIEP), 2011. Web. 23 Aug. 2013

[10] Dill, D."Through Deming's Eyes: a Cross-national Analysis of Quality Assurance Policies in Higher Education." Quality in Higher Education 1.2 (1995) : 95-110. Web. 12 March 2015.

[11] El Hassan, K. “ Quality Assurance in Higher Education in 20 MENA Economies."

Journal of Higher Education Management and Policy. 24.2 : (2013). Web. 10 January 2015.

[12] Garvin, David A. "What Does "product Quality" Really Mean?" Sloan Management Review (1984). Harvard University. Web. 20 Apr. 2015.

[13] Harman, Grant. "Quality Assurance Mechanisms and Their Use as Policy Instruments: Major International Approaches and the Australian Experience Since 1993.". The Evaluative State Revisited: $20^{\text {th }}$ Anniversary Issue of Review of Trends in Higher Education . Spec. issue of European Journal of Education 33.3 (1998) : 331348. Web. 2 Feb. 2015

[14] Harvey, L. \& Green, D. “ Defining Quality.” Assessment \& Evaluation in Higher Education.18:1 (1993): 9-34. Print.

[15]Houston, D. "Rethinking quality and improvement in higher education." Quality Assurance in Education. 16.1 (2008): 61-79. Print

[16]Jing, Xu. "A Critical Analysis of the Barriers to Achieving the Bologna Process.Frontiers of Education in China. 3.4 (2008) : 607-622. Web. Nov. 2014.

[17] Kamel, O. "L'assurance qualité dans les universités de la Méditerranée en débat." El Watan 22 Nov. 2011. Web. 15 Jan. 2014

[18]Law, D. C. S. “ Quality Assurance in Post-Secondary Education.” Quality Assurance in Education. 18.1 (2010) :, 64-77. Web. May 2015.

[19]Harvey, Lee, Williams, James. "Fifteen Years of Quality in Higher Education". Quality in Higher Education. 16.1 (2010): 3-36. Print. 
[20]Lindsay, Alan. “ Concepts of Quality in Higher Education.” Journal of Tertiary Education Administration. 14.2 (1992) : 153-163. Print.

[21]Mantz Yorke. "Assuring Quality and Standards in Globalised Higher Education." Quality Assurance in Education 7.1 (1999) : 14 - 24. Web. 1 August 2015.

[22]Miliani, Mohamed. "Building congruence between internal quality assurance and external quality assessment: The Algerian Experience." Journal of Higher Education and Science. 3.3 (2013) : 200-204 .Web. 24 Sep. 2014.

[23]Ministry of Higher Education \& Scientific Research. L'enseignement Supérieur et la Recherche Scientifique en Algérie: 50 Années au service du dévelopment 1962-2012. Algiers: 2012. Web. Available at $<$ https://www.mesrs.dz/en_GB>. 15 June 2013.

[24]Mortimer, Kenneth P. "Accountability in Higher Education." American Association for Higher Education (1972): 1-63. Web. 22 Dec. 2014.

[25]Teferra, D., Altbach, P.G. “"African Higher Education: Challenges for the 21st Century.” Higher Education 47.1 (2004) : 21-50. Web. 7 Juin 2013.

[26]Thune,Christian "The Alliance of Accountability and Improvement: the Danish Experience.” Quality in Higher Education 2.1 (1996 ): 21-32. Web. 27 July 2014.

[27]Woodhouse, David ."Quality and Quality Assurance.” Quality and Internationalisation in Higher Education. Paris: OECD Publishing, (1999). 29-40. Web. 8 May 2015. 